\title{
Kinetika izotermne kristalizacije za TPU/PP mješavine
}

\author{
E. Govorčin Bajsića* i B. Ormuž Pavić b \\ a Sveučilište u Zagrebu Fakultet kemijskog inženjerstva i tehnologije, Marulićev trg 19, 10000 Zagreb \\ ${ }^{b}$ Ministarstvo zaštite okoliša i prirode, Radnička cesta 80, 10000 Zagreb
}

Ovo djelo je dano na korištenje pod

\begin{abstract}
Sažetak
U ovom radu istražena je kinetika izotermne kristalizacije i kristalna struktura mješavina termoplastičnog poliuretana i polipropilena (TPU/PP) te termoplastičnog poliuretana i polipropilena uz dodatak talka (TPU/PP/T) različitog sastava (80/20, 50/50 i 20/80) diferencijalnom pretražnom kalorimetrijom (DSC). Kristalizacija je proučavana u području temperatura od $116{ }^{\circ} \mathrm{C}$ do $132{ }^{\circ} \mathrm{C}$. Ustanovljeno je da je kristalizacija brža za mješavine TPU/PP/T. Kinetika izotermne kristalizacije opisana je pomoću Avramijeve jednadžbe. Utjecaj različite izotermne temperature proučavan je usporedbom vrijednosti kinetičkih parametara kao što su Avramijev eksponent, $n$, kinetička konstanta brzine kristalizacije, $k$, i polovično vrijeme kristalizacije, $t_{1 / 2}$. Dobiveno je da se Avramijev eksponent kreće u rasponu od 1,18 do 2,31. Ti rezultati ukazuju na dvodimenzijski rast kristalnih jedinica. Kinetika izotermne kristalizacije pokazala je da se dodatkom talka povećava kristalište i raste konstanta brzine kristalizacije, $k$, mješavina TPU/PP. Za dane temperature kristalizacije, polovično vrijeme kristalizacije, $t_{1 / 2}$, mješavina TPU/PP/T niže je od pripadajućih vrijednosti kod mješavina TPU/PP.

Ključne riječi

Polipropilen, termoplastični poliuretan, diferencijalna pretražna kalorimetrija, izotermna kristalizacija, kinetika kristalizacije
\end{abstract}

\section{Uvod}

Analizom kristalizacije u izotermnim uvjetima moguće je dobiti parametre koji nam govore o mehanizmu rasta sferolita, dok nam analiza kristalizacije u neizotermnim uvjetima daje uvid u ponašanje polimera, polimernih mješavina, odnosno polimernih sustava u tehnološkom procesu. Za određivanje kinetike kristalizacije u neizotermnim uvjetima primjenjuje se modificirana Avramijeva jednadžba; Jeziornyjeva jednadžba, ${ }^{1}$ Ozawijev model $^{2}$ i metoda koju su razvili Mo i sur. ${ }^{3}$

Avramijeva jednadžba (jedn. 1) ima široku primjenu u opisivanju kinetike izotermne kristalizacije polimera

$$
1-X_{t}=\exp \left(-k t^{n}\right),
$$

gdje je $X_{t}$ relativna kristalnost, $k$ je konstanta brzine rasta kristala, a $n$ je Avramijev eksponent. Vrijednost Avramijevog eksponenta, $n$, ovisi o mehanizmu nukleacije i dimenzijama rasta, a parametar $k$ je funkcija nukleacije i brzine rasta kristala. Relativna kristalnost $X_{t}$ kao funkcija vremena kristalizacije definirana je jedn. (2):

$$
X_{\mathrm{t}}=\frac{\int_{0}^{\mathrm{t}}(\mathrm{d} H / \mathrm{d} t) \mathrm{d} t}{\int_{0}^{\infty}(\mathrm{d} H / \mathrm{d} t) \mathrm{d} t}=\frac{\Delta H_{\mathrm{t}}}{\Delta H_{\infty}},
$$

gdje je $\mathrm{d} H / \mathrm{d} t$ brzina promjene topline, a $t_{0}$ i $t_{\infty}$ su vremena pri kojima kristalizacija započinje, odnosno završava.

\footnotetext{
*Autor za dopisivanje: prof. dr. sc. Emi Govorčin Bajsić e-pošta: egovor@fkit.hr
}

$\Delta H_{\mathrm{t}}$ je toplina potrebna za kristalizaciju u vremenu $t$, a $\Delta H_{\infty}$ je ukupna toplina potrebna za proces kristalizacije. Proces kristalizacije sastoji se od dva stupnja: primarnog i sekundarnog i ovisi o temperaturi. Ako pretpostavimo da relativni stupanj kristalnosti raste s rastućim vremenom kristalizacije, tada se Avramijeva jednadžba može primjenjivati za analizu izotermne kristalizacije iz taljevine. Prevođenjem Avramijeve jednadžbe u logaritamski oblik dobiva se jedn. 3:

$$
\log \left[-\ln \left(1-X_{t}\right)\right]=n \log t+\log k
$$

i crtanjem ovisnosti $\log \left[-\ln \left(1-X_{\mathrm{t}}\right)\right]$ o logt dobivamo linearnu ovisnost iz čijeg nagiba možemo izračunati Avramijev eksponent $n$ i konstantu brzine rasta $k$ iz odsječka na ordinati. Polovično vrijeme kristalizacije $t_{1 / 2}$ definira se kao vrijeme u kojem je stupanj relativne kristalnosti $X_{t}$ dosegnuo $50 \%$, primjenjuje se kao mjera brzine kristalizacije. Vrijednost $t_{1 / 2}$ određuje se iz Avramijevih koeficijenata $n$ i $K$ prema sljedećem izrazu (jedn. 4):

$$
t_{1 / 2}=(\ln 2 / k)^{1 / n}
$$

\section{Eksperimentalni dio}

\subsection{Materijali}

Polimerne mješavine kao i čiste komponente pripravljene su u dvopužnom ekstruderu (Rondol $21 \mathrm{~mm}$ LAB TWIN). Prije dodavanja u ekstruder sve komponente su prethodno pomiješane i homogenizirane. Temperaturni profil ekstrudera bio je: 170/180/180/200/200/200 ${ }^{\circ} \mathrm{C}$ uz brzinu okretaja pužnih vijaka od $60 \mathrm{o} \mathrm{min}^{-1}$ do 80 o $\mathrm{min}^{-1}$. Prešanjem 
granulata polimernih mješavina i čistih komponenata dobivenih ekstruzijom, prema ISO 527-2 pripravljena su ispitna tijela injekcijskim prešanjem na injekcijskoj preši High Force 5, Rondol, pri temperaturi od $180{ }^{\circ} \mathrm{C}$. Dimenzije pripravljenih ispitnih tijela bile su približno $74 \times 5 \times 3 \mathrm{~mm}$.

\subsection{Karakterizacija}

\subsubsection{Diferencijalna pretražna kalorimetrija (DSC)}

Toplinska svojstva čistih komponenata i polimernih mješavina istražena su tehnikom diferencijalne pretražne kalorimetrije (DSC) na uređaju Mettler Toledo DSC 823e. Ispitivanja su provedena u dva ciklusa zagrijavanja - hlađenja u temperaturnom području od $-100{ }^{\circ} \mathrm{C}$ do $190{ }^{\circ} \mathrm{C}$ pri brzini $10{ }^{\circ} \mathrm{C} \mathrm{min}^{-1}$. DSC mjerenja provedena su prema metodi: čiste komponente i TPU/PP bez i s dodatkom punila zagrijane su od $25{ }^{\circ} \mathrm{C}$ do $190{ }^{\circ} \mathrm{C}$ brzinom zagrijavanja od $10{ }^{\circ} \mathrm{C} \mathrm{min}^{-1}$, uzorci su držani na temperaturi od $190{ }^{\circ} \mathrm{C} \mathrm{u}$ trajanju od $10 \mathrm{~min}$, kako bi se poništila toplinska povijest pripreme uzorka, ${ }^{4}$ nakon tog ciklusa proveden je ciklus hlađenja od $190{ }^{\circ} \mathrm{C}$ do $25{ }^{\circ} \mathrm{C}$ s tekućim dušikom kao rashladnim medijem. Masa uzoraka iznosila je 11 - 13 mg. Mjerenja su provedena u struji dušika uz protok od $40 \mathrm{ml} \mathrm{min}^{-1}$.

Iz termograma dobivenih u drugom ciklusu iz krivulja zagrijavanje/hlađenje određene su vrijednosti tališta $\left(T_{\mathrm{m}}\right)$, kristališta $\left(T_{\mathrm{c}}\right)$, entalpije taljenja $\left(\Delta H_{\mathrm{m}}\right)$, entalpije kristalizacije $\left(\Delta H_{\mathrm{c}}\right)$ i postotak kristalnosti $\left(\chi_{\mathrm{c}}\right)$ preko izraza (jedn. 5):

$$
\chi_{\mathrm{c}}=\frac{\Delta H_{\mathrm{m}}^{\mathrm{o}}}{\Delta H_{\mathrm{m}}^{100}} \cdot 100,
$$

gdje je $\Delta H_{\mathrm{m}}{ }^{0}$ toplina taljenja dobivena mjerenjem DSC, a $\Delta H_{\mathrm{m}}{ }^{100}$ toplina taljenja $100 \%$ kristalnog izotaktnog PP-a, koja iznosi $165 \mathrm{~J} \mathrm{~g}^{-1} .{ }^{5}$ Za određivanje kinetike kristalizacije u izotermnim uvjetima primijenjena je metoda kako slijedi:

1. zagrijavanje uzorka od 25 do $200{ }^{\circ} \mathrm{C}$ brzinom zagrijavanja od $10{ }^{\circ} \mathrm{C} \mathrm{min}^{-1}$

2. izotermna stabilizacija uzorka na $200{ }^{\circ} \mathrm{C}$ u vremenu od $10 \mathrm{~min}$

3. brzo hlađenje od $200{ }^{\circ} \mathrm{C}$ brzinom hlađenja od $100{ }^{\circ} \mathrm{C} \mathrm{min}^{-1}$ do temperature izotermne kristalizacije $\left(T_{\mathrm{ci}}\right.$ od 116 do $\left.132{ }^{\circ} \mathrm{C}\right)$

4. izotermna kristalizacija u vremenu od $30 \mathrm{~min}$

5. hlađenje od $T_{\mathrm{ci}}$ do $25{ }^{\circ} \mathrm{C}$ brzinom od $10{ }^{\circ} \mathrm{C} \mathrm{min}^{-1}$

6. zagrijavanje do $200{ }^{\circ} \mathrm{C}$ brzinom od $10{ }^{\circ} \mathrm{C} \mathrm{min}^{-1}$

7. hlađenje od 200 do $25{ }^{\circ} \mathrm{C}$ brzinom od $10{ }^{\circ} \mathrm{C} \mathrm{min}^{-1}$

\section{Rezultati i rasprava}

\subsection{Rezultati DSC mjerenja dobiveni prije izotermne kristalizacije}

Prije mjerenja kinetike izotermne kristalizacije provedena su mjerenja DSC grijanja/hlađenja na osnovi kojih je odre- đeno talište, $T_{\mathrm{m}}$, kristalište $T_{\mathrm{c}}$ i entalpije taljenja, $\Delta H_{\mathrm{m}}$ i hlađenja $\Delta H_{\mathrm{c}}$ kako bi se dobile vrijednosti navedenih toplinskih svojstava prije izotermne kristalizacije s ciljem njihove usporedbe s vrijednostima nakon izotermne kristalizacije. Na slici 1 prikazani su endotermi taljenja (slika 1a) i egzotermi kristalizacije (slika 1b) za sve mješavine TPU/PP i $\mathrm{TPU} / \mathrm{PP} / \mathrm{T}$ dobivene pri brzini zagrijavanja od $10{ }^{\circ} \mathrm{C} \mathrm{min}^{-1}$, vrijednosti dobivene iz krivulja unesene su u tablicu 2. Pojava jednog endotermnog pika taljenja i jednog egzotermnog pika kristalizacije za sve mješavine TPU/PP bez dodatka i s dodatkom talka ukazuju istodobnu kristalizaciju TPU-a i PP-a. Talište kristalastih polimera ovisno je o veličini i sređenosti kristala. Dodatak amorfnog TPU-a u PP onemogućava rast kristala PP-a, odnosno dovodi do stvaranja malih nesavršenih kristala PP-a. Vrijednosti tališta u svim mješavinama bez talka dobivene su na istoj temperaturi od $\sim 164{ }^{\circ} \mathrm{C}$. Tališta mješavina TPU/PP u koje je dodan talk pomiču se na neznatno višu temperaturu u odnosu na čisti PP i mješavine istog udjela TPU-a i PP-a bez dodatka talka što može ukazivati na stvaranje većih kristala. Endotermi taljenja sužavaju se i povećava im se intenzivnost povećanjem udjela PP-a i dodatkom talka. Na slici 1b prikazani su egzotermi kristalizacije iz kojih su očitane vrijednosti kristališta. Dodatkom talka maksimum kristalizacije pomiče se na znatno višu temperaturu. Takvo ponašanje može se dovesti u vezu s nukleacijskim djelovanjem talka, što dovodi do prestrukturiranja u kristalnoj strukturi.
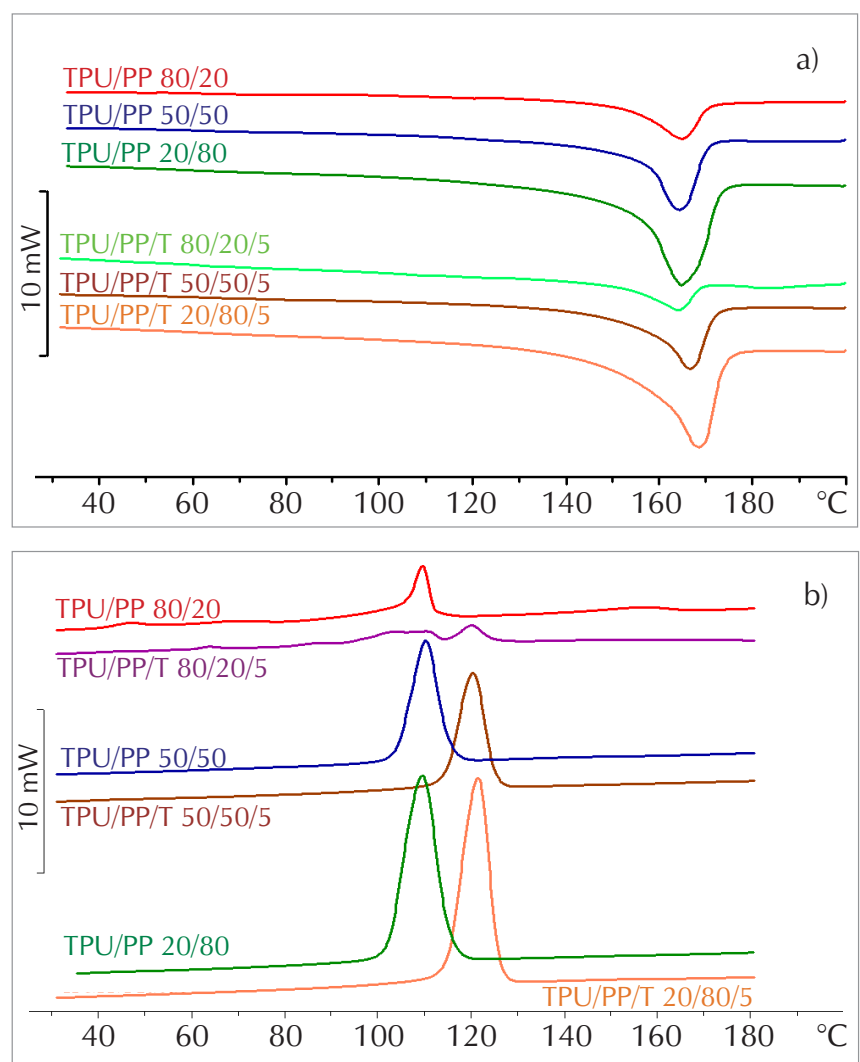

Slika 1 - a) Endotermi taljenja i b) egzotermi kristalizacije mješavina TPU/PP uz različit udjel PP-a

Fig. 1 - a) Melting endotherms, and b) crystallization exotherms of TPU/PP blends at different PP ratios 
Na slici 2 prikazan je odnos između tališta mješavina TPU/ PP bez dodatka i s dodatkom talka i udjela PP-a. Povećanjem udjela PP-a vrijednosti $T_{m}$ ostaju gotovo na istim temperaturama, dok se dodatkom talka tališta pomiču prema višim temperaturama, što ukazuje na stvaranje savršenije kristalne strukture PP-a.

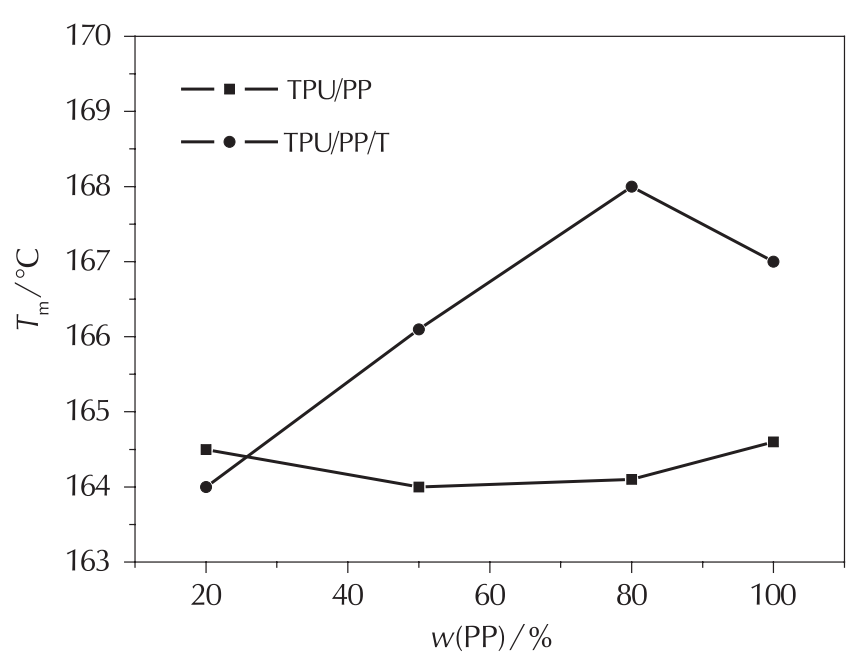

Slika 2 - Ovisnost temperature taljenja o udjelu polipropilena u mješavinama TPU/PP i TPU/PP/T

Fig. 2 -Dependence of melting temperature on PP fraction in TPU/PP and TPU/PP/T blends

Odnos između kristališta, $T_{\mathrm{c}}$ i udjela PP-a prikazan je na slici 3. Iz grafičkog prikaza vidi se da vrijednosti $T_{\mathrm{c}}$ rastu $u$ mješavinama bez dodatka talka kod manjih udjela PP-a. Dodatkom talka (mješavine TPU/PP/T) vrijednosti $T_{\mathrm{c}}$ se povisuju porastom udjela PP-a u mješavinama, što može biti posljedica interakcija na međupovršini između talka i PP-a. Uslijed interakcija dolazi do brže kristalizacije pri procesu hlađenja. ${ }^{6}$

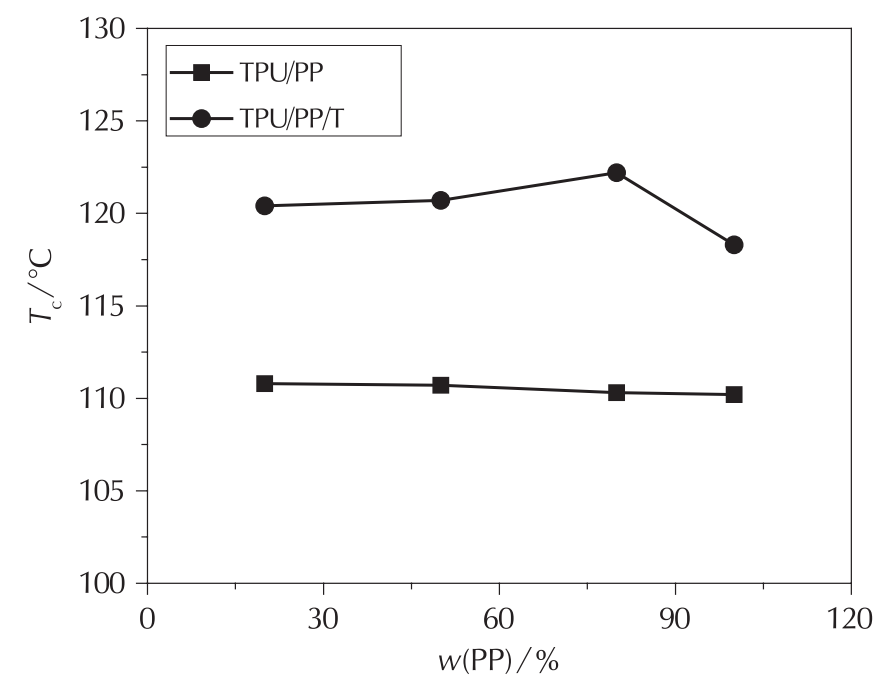

Slika 3 - Ovisnost temperature kristalizacije o udjelu polipropilena u mješavinama TPU/PP i TPU/PP/T

Fig. 3 -Dependence of crystallization temperature on PP fraction in TPU/PP and TPU/PP/T blends

Krivulje ovisnosti postotka kristalnosti o udjelu PP-a za mješavine TPU/PP bez dodatka i s dodatkom talka prikazane su na slici 4. Vidljivo je da postotak kristalnosti raste s povećanjem udjela PP-a u svim istraženim mješavinama TPU/PP i TPU/PP/T. Također je vidljivo da se krivulja $\chi_{\mathrm{d}} / w(\mathrm{PP})$ za mješavine TPU/PP/T nalazi ispod krivulje mješavina TPU/PP, odnosno da se neznatno smanjuje kristalnost PP-a. To ponašanje može se objasniti time da kod procesa taljenja segmenti amorfne faze dinamičkim tečenjem prelaze u kristalnu fazu PP-a i narušavaju strukturu kristalne faze, što može imati posljedicu smanjenja kristalnosti. ${ }^{7}$ Posljedica smanjenja kristalnosti može biti i stvaranje aglomerata.

Tablica 1 - Prikaz rezultata dobivenih mjerenjem DSC

Table 1 - Results obtained by DSC measurements

\begin{tabular}{|c|c|c|c|c|c|c|c|}
\hline $\begin{array}{l}\text { Uzorak } \\
\text { Sample }\end{array}$ & $T_{\text {m,onset }} /{ }^{\circ} \mathrm{C}$ & $T_{\mathrm{m}} /{ }^{\circ} \mathrm{C}$ & $\Delta H_{\mathrm{m}} / \mathrm{Jg}^{-1}$ & $T_{\text {c,onset }} /{ }^{\circ} \mathrm{C}$ & $T_{\mathrm{c}} /{ }^{\circ} \mathrm{C}$ & $\Delta H_{\mathrm{c}} / \mathrm{Jg}^{-1}$ & $\chi_{\mathrm{c}} / \%$ \\
\hline PP & 143,5 & 164,6 & 69,37 & 117,1 & 110,2 & 68,79 & 41,6 \\
\hline $\begin{array}{c}\mathrm{PP} / \mathrm{T} \\
100 / 5\end{array}$ & 148,1 & 167,0 & 40,86 & 112,3 & 118,3 & 47,09 & 28,5 \\
\hline $\begin{array}{c}\text { TPU/PP } \\
80 / 20\end{array}$ & 144,1 & 164,5 & 19,34 & 112,7 & 110,8 & 12,01 & 7,3 \\
\hline $\begin{array}{c}\text { TPU/PP } \\
50 / 50\end{array}$ & 146,9 & 164,0 & 33,76 & 115,8 & 110,7 & 31,80 & 19,3 \\
\hline $\begin{array}{c}\text { TPU/PP } \\
20 / 80\end{array}$ & 148,9 & 164,1 & 59,27 & 116,3 & 110,3 & 58,15 & 35,2 \\
\hline TPU/PP/T 80/20/5 & 147,4 & 164,0 & 12,51 & 125,3 & 120,4 & 11,73 & 7,1 \\
\hline TPU/PP/T 50/50/5 & 145,5 & 166,1 & 33,14 & 125,4 & 120,7 & 30,94 & 18,8 \\
\hline TPU/PP/T 20/80/5 & 142,6 & 168,0 & 58,47 & 126,3 & 122,2 & 55,45 & 33,6 \\
\hline
\end{tabular}




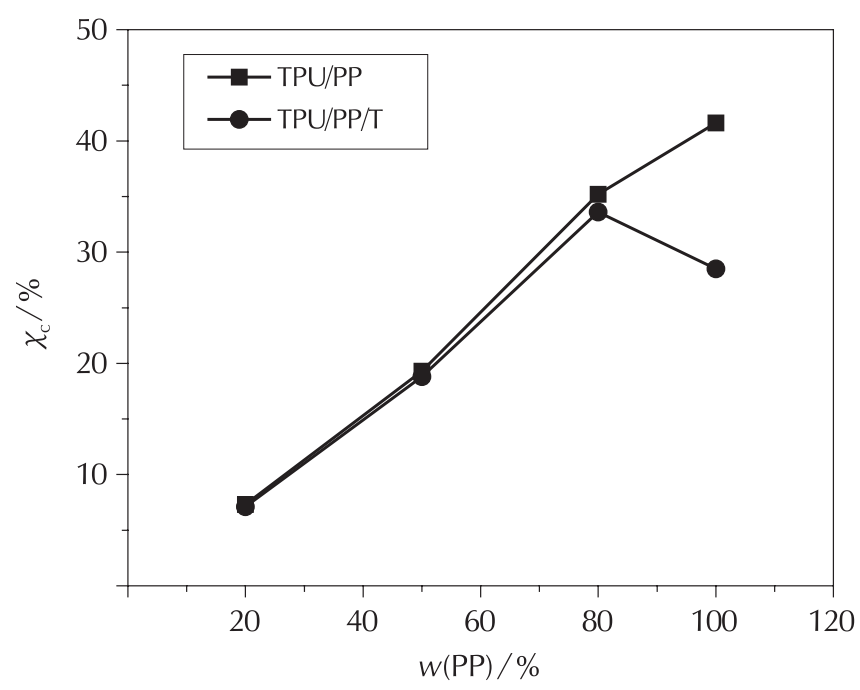

Slika 4 - Grafički prikaz ovisnost stupnja kristalnosti o udjelu polipropilena u mješavinama TPU/PP i TPU/PP/T

Fig. 4 - Plots of crystallinity degree vs. PP fraction in TPU/PP i TPU/PP/T blends

\subsection{Rezultati mjerenja DSC dobiveni nakon izotermne kristalizacije}

U nastavku rada istražen je utjecaj temperature kristalizacije u mješavinama TPU/PP na kinetiku kristalizacije u izotermnim uvjetima. Analiza kinetike izotermne kristalizacije PP-a, PP/talk i mješavina TPU/PP bez dodatka i s dodatkom talka $(w(t a l k)=5 \%)$ provedena je mjerenjem DSC. Odabrano je pet temperatura izotermne kristalizacije $\left(T_{\mathrm{ci}}\right): 116{ }^{\circ} \mathrm{C}, 120{ }^{\circ} \mathrm{C}, 124{ }^{\circ} \mathrm{C}, 128{ }^{\circ} \mathrm{C}$ i $132{ }^{\circ} \mathrm{C}$ pri kojima je uzorak termostatiran $30 \mathrm{~min}$. Analiza eksperimentalnih podataka provedena je primjenom Avramijeva modela. Izotermni termogrami dobiveni hlađenjem rastaljenog PP-a, PP/talk i mješavina TPU/PP bez dodatka i s dodatkom talka na različite temperature prikazani su na slikama $5-8$, iz kojih je vidljiv utjecaj različitih temperatura na stupanj kristalnosti. Iz krivulja čistog PP-a (slika 5a) vidljivo je da temperatura ima velik utjecaj na kinetiku kristalizacije. Slično ponašanje dobiveno je za PP u koji je dodan talk (slika 5b). Povišenjem temperature kristalizacije dolazi do pomaka egzoterma kristalizacije na dulje vrijeme kristalizacije, njihova proširenja i smanjenja intenzivnosti. To podra-
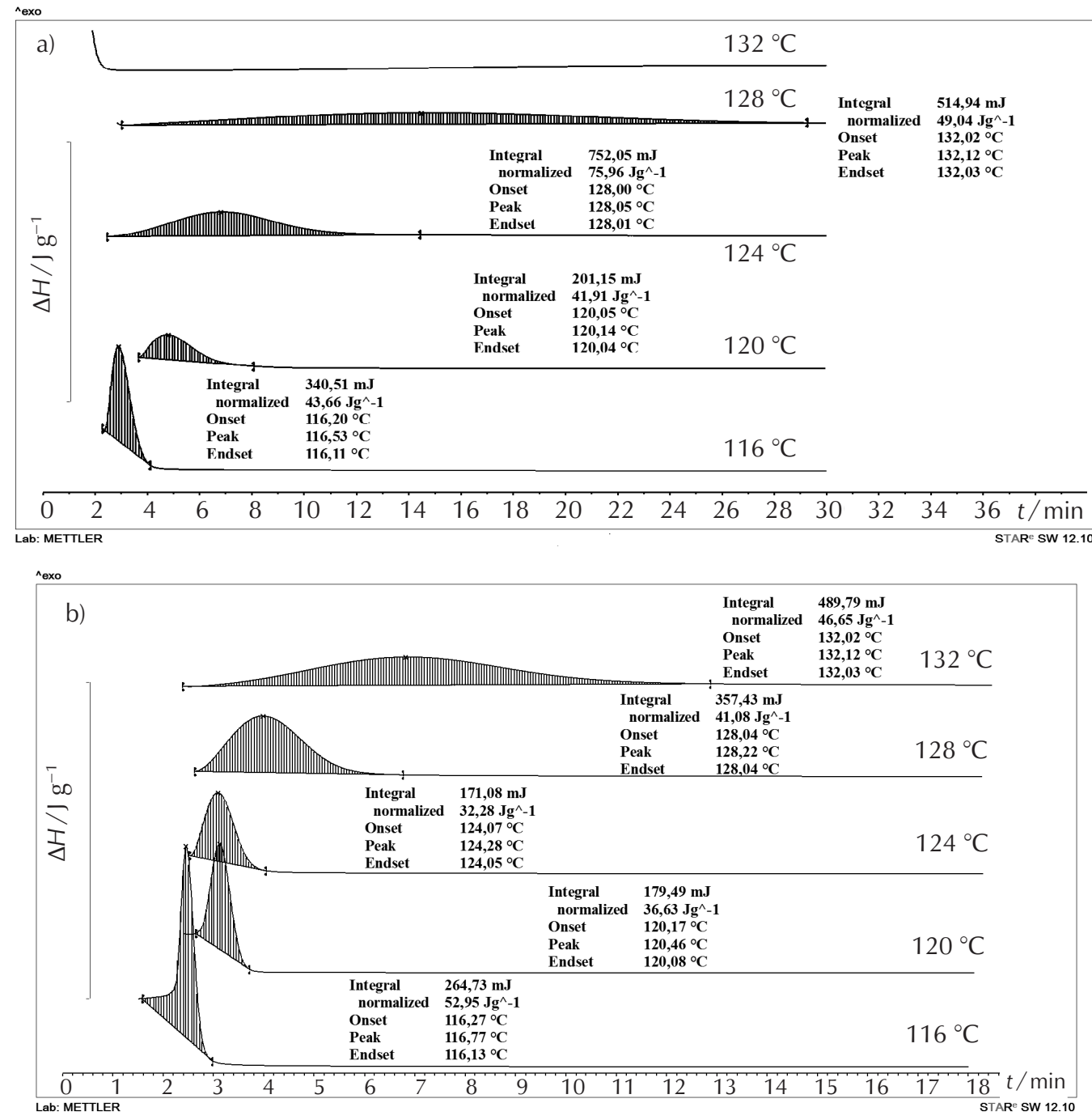

Slika 5 - Termogrami DSC za a) čisti PP i b) PP/talk 100/5 pri različitim temperaturama kristalizacije

Fig. 5 - DSC thermograms of a) neat PP, and b) PP/talc 100/5 at different temperatures of crystallization 
zumijeva da je ukupno vrijeme kristalizacije produljeno i da dolazi do pada stupnja kristalnosti povišenjem $T_{\text {ci }}$.

Na slikama 6 - 8 prikazani su termogrami DSC za mješavine TPU/PP bez dodatka i s dodatkom talka pri različitim temperaturama kristalizacije. Vidljivo je da povećanjem udjela PP-a raste stupanj kristalnosti PP-a, koji se dalje povećava dodatkom talka. Ukupna kristalizacija, kako je vidljivo iz egzotermnog pika kristalizacije na svim temperaturama izotermne kristalizacije, $T_{\text {ci, }}$ završava u kraćem vremenu kod većeg udjela PP-a i dodatkom talka. Mješavine u koje je dodan talk brže kristaliziraju u odnosu na mješavine bez dodatka talka, kao i mješavine u koje je dodan veći udio polipropilena. Povećanjem temperature kristalizacije pik kristalnosti pomiče se prema duljim vremenima kristalizacije i postaje širi (manja intenzivnost pika). Dobiveni rezultati ukazuju na smanjenje ukupnog vremena kristalizacije povećanjem temperature izotermne kristalizacije $T_{\mathrm{c}}$.

Proučavanje ukupne kinetike izotermne kristalizacije kristalastih polimera temelji se na pretpostavci da je razvoj kristala linearno ovisan o oslobođenoj toplini u procesu kristalizacije. ${ }^{8,9}$ Kako bi se odredila relativna kristalnost $X_{\mathrm{t}} \mathrm{u}$ funkciji vremena prema jedn. 1 iz eksperimentalno dobivenih krivulja, provedena je postupna integracija dijelova krivulje izotermne kristalizacije u funkciji vremena (jedn. 2). Promjena relativne kristalnosti izračunate prema jedn. 3 u funkciji vremena izotermne kristalizacije za sve istražene uzorke prikazana je na slikama $9-11$, osim za mješavine TPU/PP 80/20 i TPU/PP/talk 80/20/5 (slike 6a i 6b), kao i za mješavine TPU/PP 50/50 i 20/80 bez dodatka talka. Pri temperaturi izotermne kristalizacije od $132{ }^{\circ} \mathrm{C}$
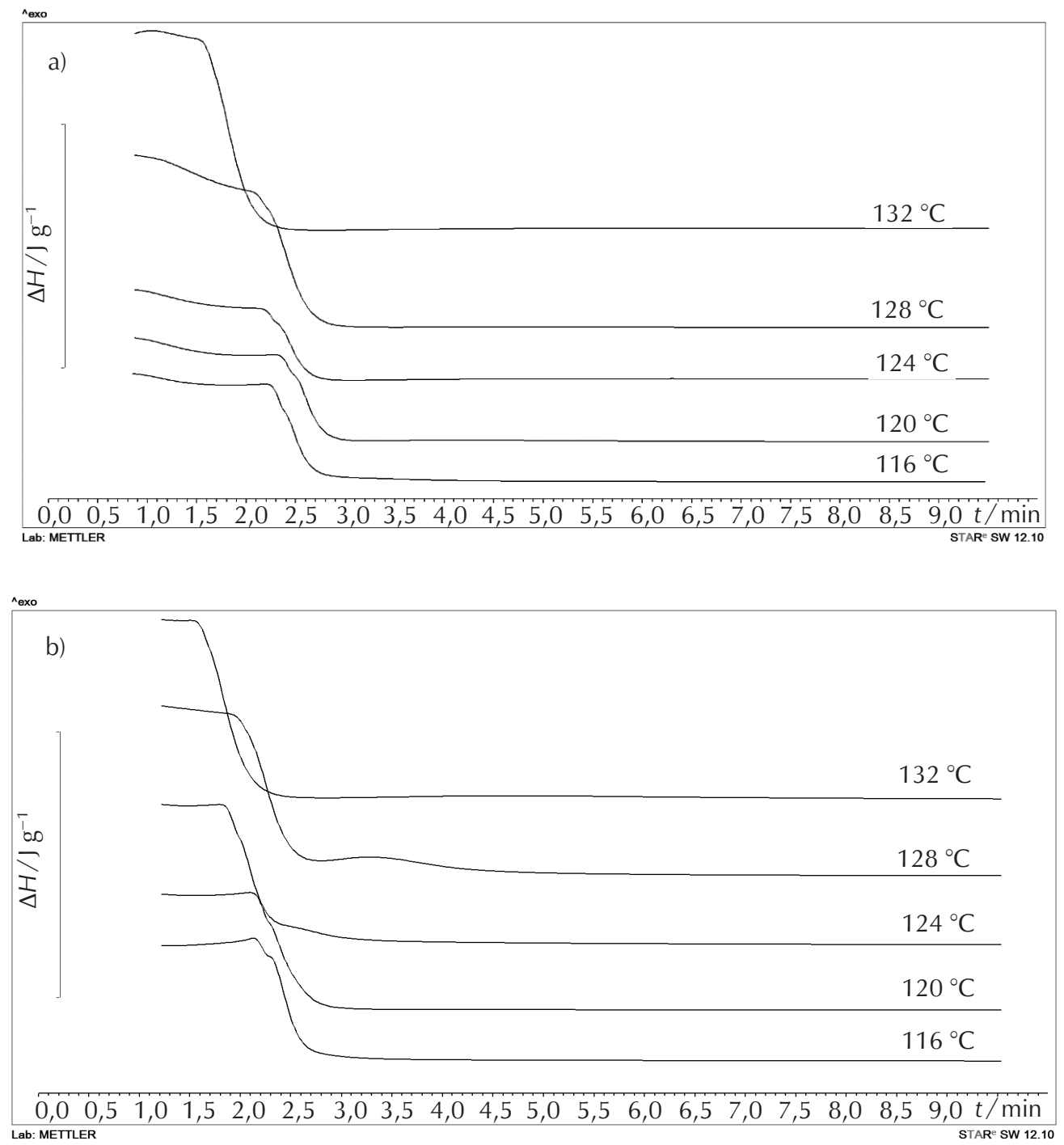

Slika 6 - Termogrami DSC za a) TPU/PP 80/20 i b)TPU/PP/talk 80/20/5 pri različitim temperaturama kristalizacije

Fig. 6 - DSC thermograms of a) TPU/PP 80/20, and b) TPU/PP/talc 80/20/5 at different temperatures of crystallization 

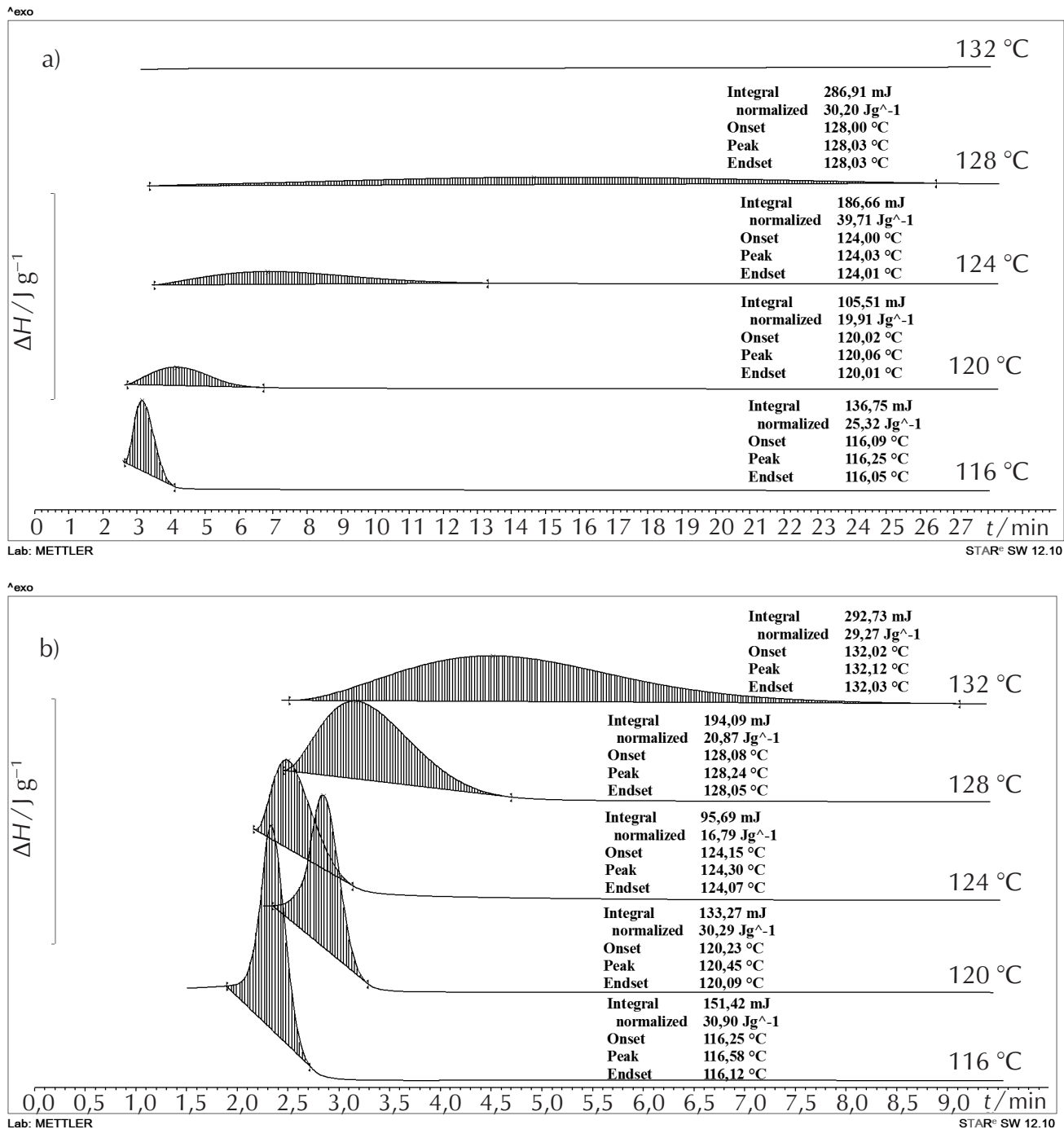

Slika 7 - Termogrami DSC za a) TPU/PP 50/50 i b)TPU/PP/talk 50/50/5 pri različitim temperaturama kristalizacije

Fig. 7 - DSC thermograms of a) TPU/PP 50/50, and b) TPU/PP/talc 50/50/5 at different temperatures of crystallization

(slike 7a i 8a), kod navedenih mješavina TPU/PP nije dobiven egzoterm kristalizacije, tako da za te mješavine nije određena kinetika kristalizacije koja je istraživana u nastavku rada.

Za sve analizirane uzorke sve krivulje ovisnosti relativne kristalnosti o vremenu imaju oblik "S". Na osnovi dobivenih rezultata vidljivo je da stupanj kristalnosti raste $u$ prisustvu talka i može se zaključiti da se relativna količina kristalnosti razvijena kod određenog vremena $t$ smanjuje povišenjem temperature izotermne kristalizacije i da talk djeluje kao nukleacijski agens za PP, neovisno o temperaturi kristalizacije. Početak sekundarne kristalizacije preklapa se sa "sudarom" između sferolita. Kad su sudari neznatni, vrijeme potrebno za popunjavanje međuprostora je prekratko i sekundarni proces kristalizacije (ako postoji) je ograničen. Kako bi se odredili parametri kinetike kristalizacije $n$ i $K$, vrijednosti relativne kristalnosti $X_{\mathrm{t}}$ u ovisnosti o vremenu analizirani su Avramijevim modelom. Prema tom modelu ovisnost $\log \left[-\ln \left(1-X_{\mathrm{t}}\right)\right]$ o logt koja se odnosi na primarnu kristalizaciju pri kojoj dolazi do rasta nukleusa te stvaranja i rasta sferolita trebala bi biti linearna (jedn. 3). Za određivanje kinetičkih parametara primjenjuje se samo linearni dio dobivenih krivulja $\log \left[-\ln \left(1-X_{\mathrm{t}}\right)\right]$ o logt (slike 12-14). 

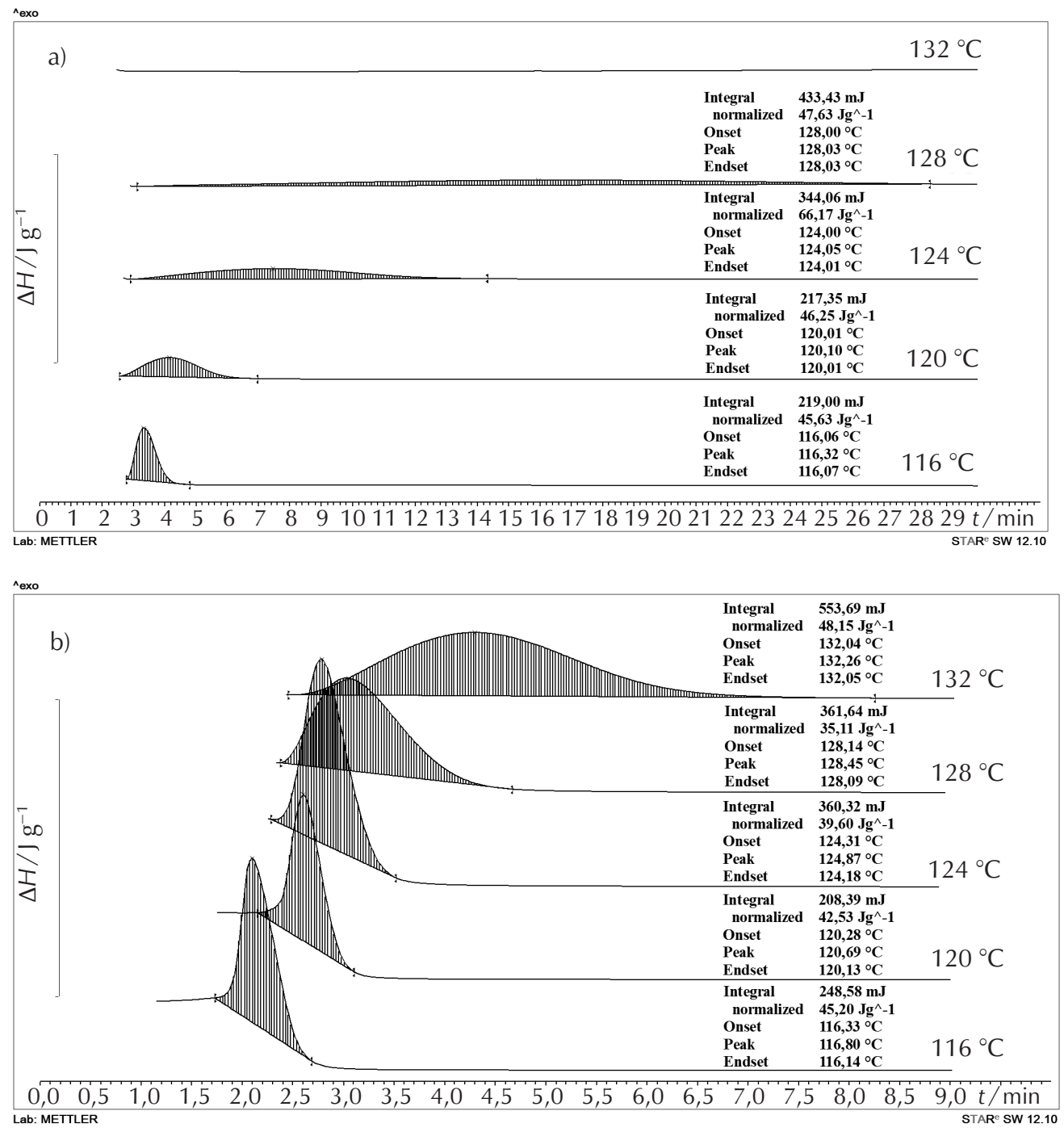

Slika 8 - Termogrami DSC za a) TPU/PP 20/80 i b)TPU/PP/talk 20/80/5 pri različitim temperaturama kristalizacije

Fig. 8 - DSC thermograms of a) TPU/PP 20/80, and b) TPU/PP/talc 20/80/5 at different temperatures of crystallization
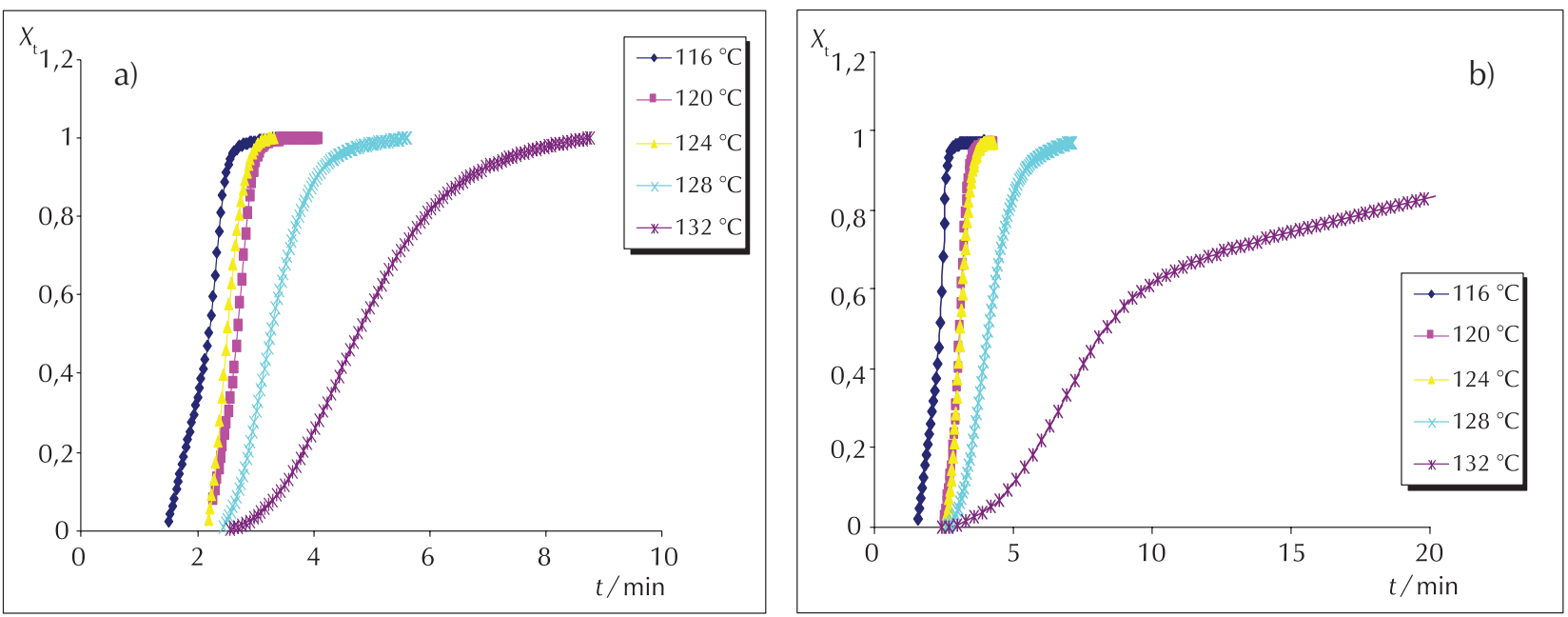

Slika 9 - Ovisnost relativne kristalnosti o vremenu kristalizacije pri različitim temperaturama za a) čisti PP i b) PP/talk Fig. 9 - Relative crystallinity as a function of time at different temperatures for a) neat PP, and b) PP/talc 

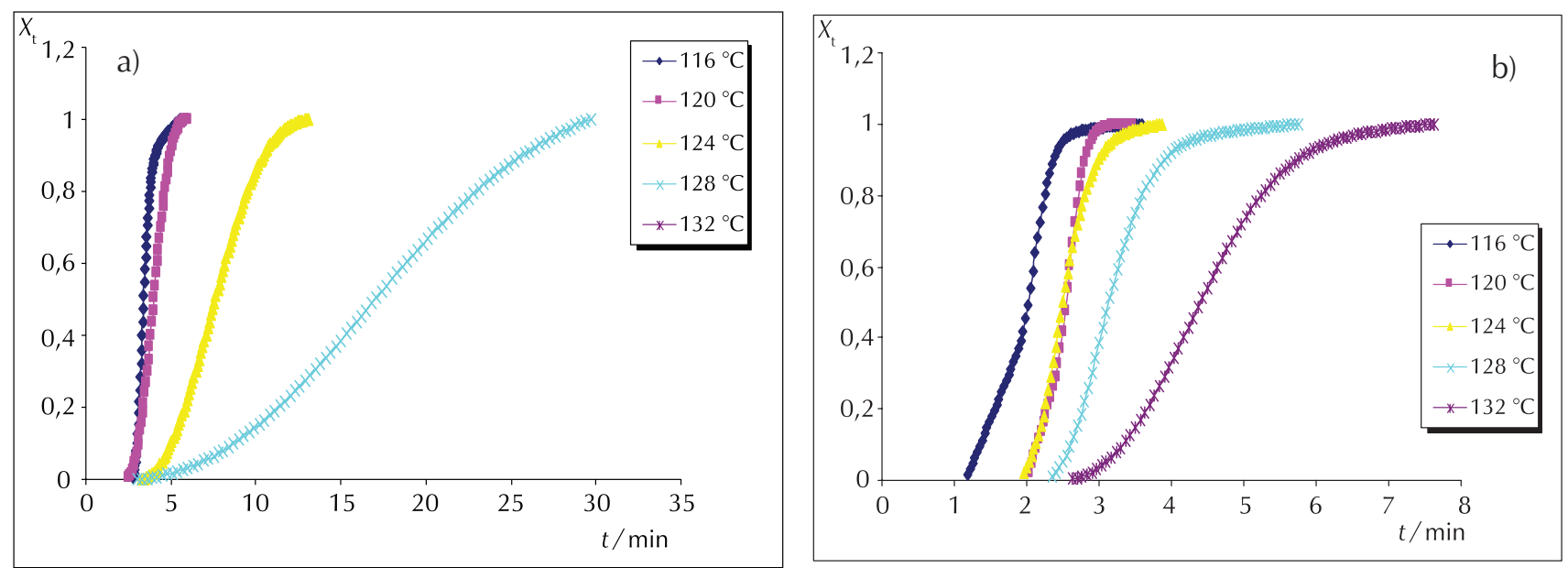

Slika 10 - Ovisnost relativne kristalnosti o vremenu kristalizacije pri različitim temperaturama za mješavine a) TPU/PP 50/50 i b) TPU/PP/talk 50/50/5

Fig. 10 - Relative crystallinity as a function of time at different temperatures for a) TPU/PP 50/50, and b) TPU/PP/talc 50/50/5 blends
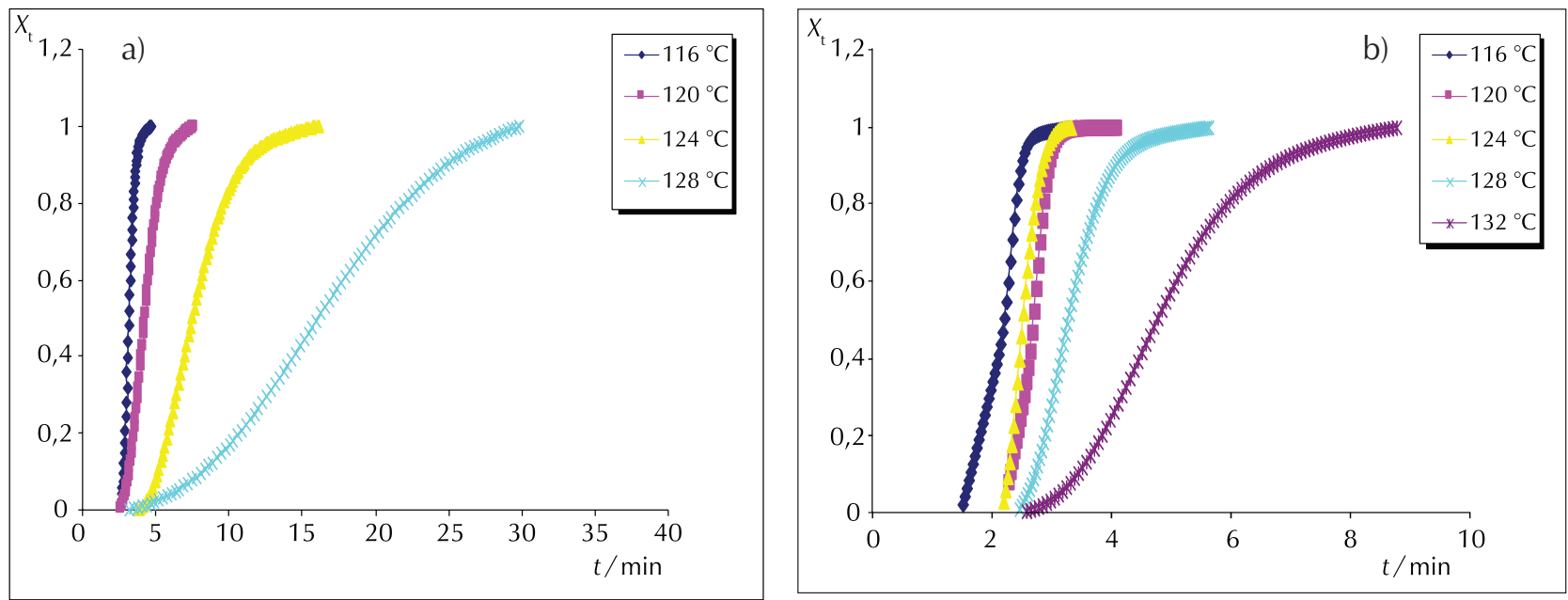

Slika 11 - Ovisnost relativne kristalnosti o vremenu kristalizacije pri različitim temperaturama za mješavine a) TPU/PP 20/80 i b) TPU/PP/talk 20/80/5

Fig. 11 - Relative crystallinity as a function of time at different temperatures for a) TPU/PP 20/80, and b) TPU/PP/talc 20/80/5 blends
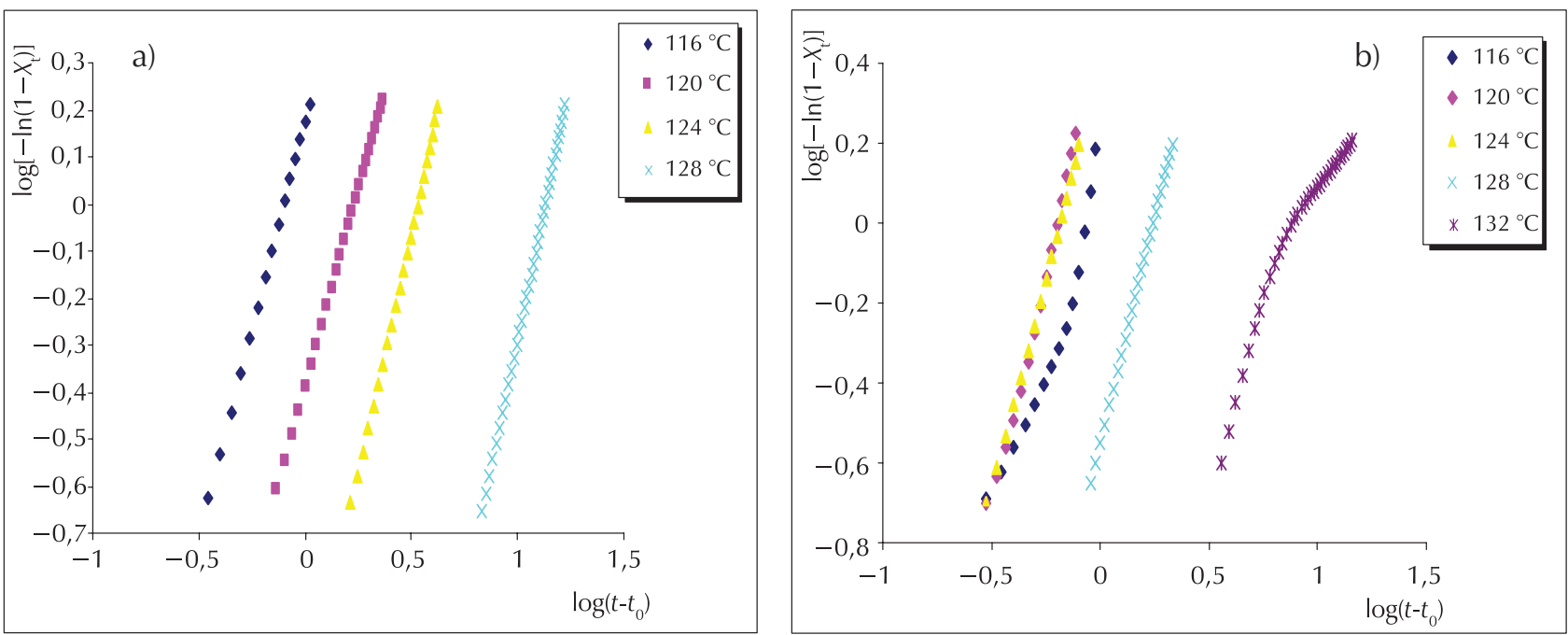

Slika 12 - Ovisnost $\log \left[-\ln \left(1-X_{\mathrm{t}}\right)\right]$ o logt pri različitim temperaturama za a) čisti PP i b) PP/talk 100/5 prema Avramijevu modelu Fig. $12-$ Avrami plots of $\log \left[-\ln \left(1-X_{\mathrm{t}}\right)\right]$ vs. logt at different temperatures for a) neat PP, and b) PP/talc 

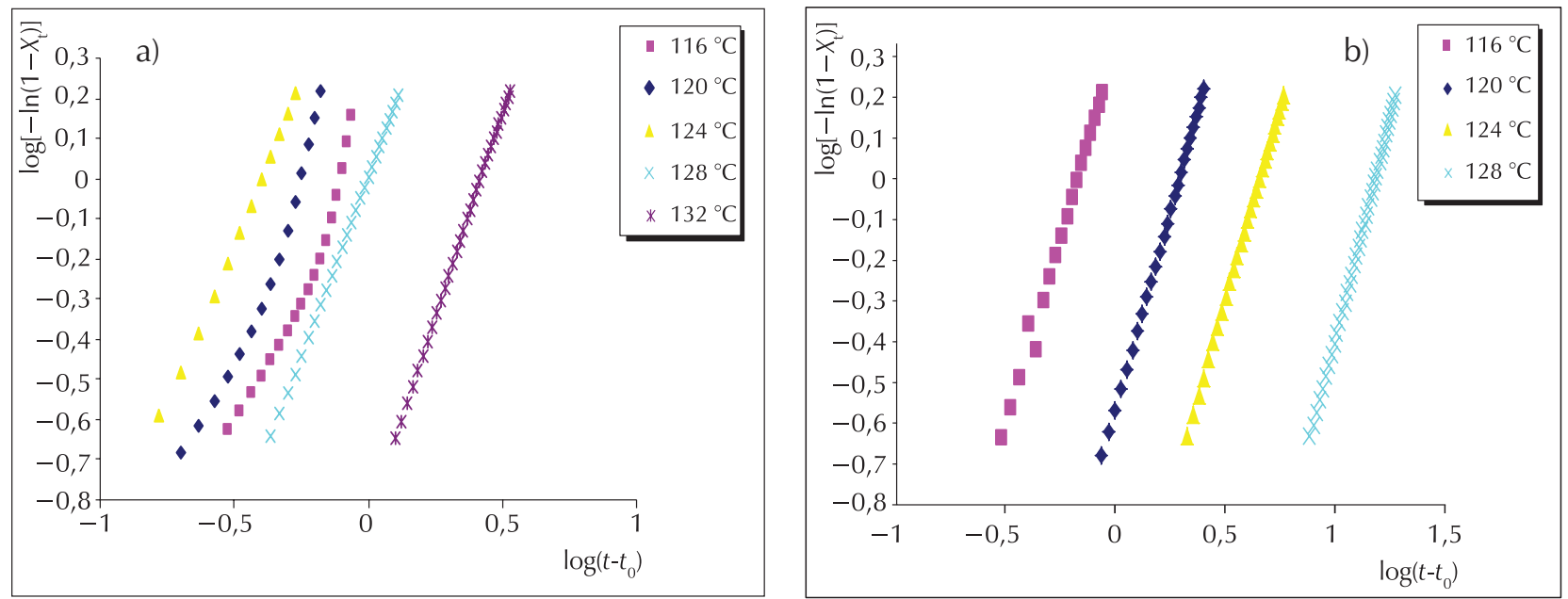

Slika 13 - Ovisnost $\log \left[-\ln \left(1-X_{\mathrm{t}}\right)\right]$ o logt pri različitim temperaturama za mješavine a) TPU/PP 50/50 i b) TPU/PP/talk 50/50/5 prema Avramijevu modelu

Fig. 13 - Avrami plots of $\log \left[-\ln \left(1-X_{\mathrm{t}}\right)\right]$ vs. logt at different temperatures for a) 50/50, and b) TPU/PP/talc 50/50/5 blends
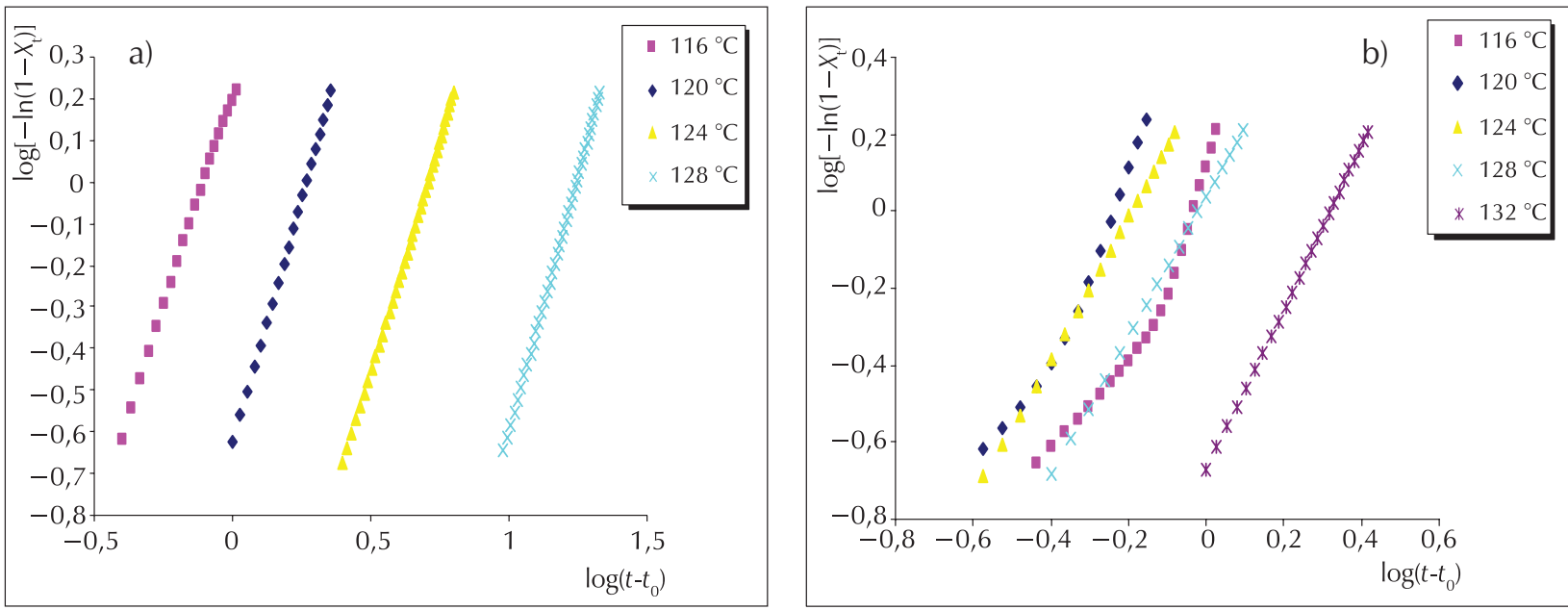

Slika 14 - Ovisnost $\log \left[-\ln \left(1-X_{\mathrm{t}}\right)\right]$ o logt pri različitim temperaturama za mješavine a) TPU/PP 20/80 i b) TPU/PP/talk 20/80/5 prema Avramijevu modelu

Fig. 14 - Avrami plots of $\log \left[-\ln \left(1-X_{t}\right)\right]$ vs. logt at different temperatures for a) 20/80, and b) TPU/PP/talc 20/80/5 blends

Iz nagiba pravca određuje se parametar $n$, dok se parametar $k$ određuje iz odsječka pravca na ravnom dijelu krivulje. Konstanta Avramijevog eksponenta $n$ definira određenu morfologiju kristalne strukture i broj nukleusa, a $k$ definira brzinu kristalizacije za pojedine uvjete kristalizacije. Prema literaturnim podatcima vrijednost Avramijevog eksponenta $n$ kreće se u području vrijednosti od 1 do $4 .{ }^{10}$ Vrijednosti parametra $n$ navedene su u tablici 2. Na osnovi eksperimentalnih vrijednosti dobivenih iz termograma vidljivo je da Avramijev eksponent $n$ raste dodatkom talka ovisno o temperaturi izotermne kristalizacije. Ovisno o temperaturi izotermne kristalizacije parametar $n$ kreće se u rasponu od 1,18 do 2,31 za čisti PP i PP/talk i unutar područja od 1,59 do 2,48 za mješavine TPU/PP i TPU/PP/talk. Prema definiciji Avramijevog eksponenta, kad je vrijednost $n$ oko 2,0, proces nukleacije je istodoban i rast kristala je vjerojatno dvodimenzionalan prema toplinskom mehanizmu nukle- acije. ${ }^{11}$ Povećanjem udjela PP-a Avramijev eksponent raste. Dodatkom talka u svim mješavinama TPU/PP/talk $n$ je uglavnom manji od 2. Parametar Avramijeva modela $K$ koji definira brzinu kristalizacije znatno ovisi o nagibu pravca, odnosno vrijednosti parametra $n$. Iz tablice 2 vidljivo je da vrijednosti Avramijeve konstante $K$ za mješavine PP i TPU/

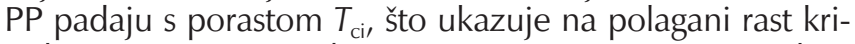
stala PP-a. Smanjenje $k$ u ovisnosti o temperaturi rezultira iz činjenice da je eksperimentalna temperatura kristalizacije viša od temperature maksimalne brzine kristalizacije. Nadalje, dodatak nukleacijskog agensa (mješavine PP/talk i TPU/PP/talk) dovodi do povećanja kinetičkog parametra $k$ s porastom $T_{\mathrm{ci}}$ negdje do izotermne temperature od $124{ }^{\circ} \mathrm{C}$ (tablica 2), što ukazuje na bržu kristalizaciju PP-a. Avramijeva konstanta $k$, koja kontrolira kristalizaciju uzorka i iznimno je osjetljiva na temperaturu, određuje i brzinu nukleacije i proces rasta kristala. Vrijednost konstante $k$ ovisna je 
o molekulskoj masi i strukturi polimera, raspodjeli molekulske mase, prisutnosti nečistoća i nukleacijskog agensa. ${ }^{11}$

Tablica 2 - Vrijednosti parametara izotermne kristalizacije

Table 2 - Parameters of isothermal crystallization

\begin{tabular}{|c|c|c|c|c|c|}
\hline $\begin{array}{l}\text { Uzorak } \\
\text { Sample }\end{array}$ & $T_{\mathrm{ci}} /{ }^{\circ} \mathrm{C}$ & $\log k$ & $k$ & $n$ & $t_{1 / 2} / \min$ \\
\hline \multirow{5}{*}{ PP } & 116 & 0,1752 & 1,49693 & 1,77 & 0,64727 \\
\hline & 120 & $-0,3869$ & 0,41030 & 1,67 & 1,36887 \\
\hline & 124 & $-1,0915$ & 0,08100 & 2,06 & 2,83521 \\
\hline & 128 & $-2,5001$ & 0,00316 & 2,21 & 11,46152 \\
\hline & 132 & - & - & - & - \\
\hline \multirow{5}{*}{$\begin{array}{l}\mathrm{PP} / \text { talk } \\
100 / 5\end{array}$} & 116 & 0,0675 & 1,16815 & 1,59 & 0,72017 \\
\hline & 120 & 0,4596 & 2,88138 & 2,31 & 0,53968 \\
\hline & 124 & 0,3887 & 2,44737 & 2,08 & 0,54525 \\
\hline & 128 & $-0,5378$ & 0,28987 & 2,23 & 1,47838 \\
\hline & 132 & $-1,0984$ & 0,07973 & 1,18 & 6,25106 \\
\hline \multirow{5}{*}{$\begin{array}{c}\text { TPU/PP } \\
50 / 50\end{array}$} & 116 & 0,3294 & 2,13305 & 1,86 & 0,51644 \\
\hline & 120 & $-0,5682$ & 0,27046 & 1,95 & 1,62033 \\
\hline & 124 & $-1,2568$ & 0,08100 & 1,91 & 3,75193 \\
\hline & 128 & $-2,5603$ & 0,00316 & 2,17 & 12,77937 \\
\hline & 132 & - & - & - & - \\
\hline \multirow{5}{*}{$\begin{array}{l}\text { TPU/PP } \\
\text { 20/80 }\end{array}$} & 116 & 0,2079 & 1,61399 & 2,05 & 0,66212 \\
\hline & 120 & 0,2079 & 1,61399 & 2,37 & 0,70003 \\
\hline & 124 & $-1,5678$ & 1,56780 & 2,22 & 4,31038 \\
\hline & 128 & $-3,0805$ & 0,00083 & 2,48 & 15,06447 \\
\hline & 132 & - & - & - & - \\
\hline \multirow{5}{*}{$\begin{array}{c}\text { TPU/PP/talk } \\
50 / 50 / 5\end{array}$} & 116 & 0,1343 & 1,36239 & 1,59 & 0,65377 \\
\hline & 120 & 0,4245 & 2,65766 & 1,72 & 0,45778 \\
\hline & 124 & 0,6403 & 4,36818 & 1,61 & 0,31874 \\
\hline & 128 & 0,0033 & 1,00763 & 1,79 & 0,81140 \\
\hline & 132 & $-0,8555$ & 0,13948 & 2,10 & 2,19586 \\
\hline \multirow{5}{*}{$\begin{array}{c}\text { TPU/PP/talk } \\
20 / 80 / 5\end{array}$} & 116 & 0,0313 & 1,07399 & 1,83 & 0,78719 \\
\hline & 120 & 0,5027 & 3,17468 & 2,13 & 0,48948 \\
\hline & 124 & 0,3477 & 2,22690 & 1,84 & 0,53030 \\
\hline & 128 & 0,0329 & 1,07870 & 1,83 & 0,75531 \\
\hline & 132 & $-0,6857$ & 0,20621 & 2,14 & 1,76265 \\
\hline
\end{tabular}

Vrijednosti polovičnog vremena kristalizacije $t_{1 / 2}$ obrnuto su proporcionalne brzini kristalizacije. Općenito se polovično vrijeme $t_{1 / 2}$ može primjenjivati za karakterizaciju kristalizacije. Dulje polovično vrijeme ukazuje na sporiju kristalizaciju. Na osnovi krivulja ovisnosti $t_{1 / 2}$ o $T_{\text {ci }}$ prikaza- nih na slici 15 i vrijednosti $t_{1 / 2}$ prikazanih u tablici 2 vidljivo je da vrijeme $t_{1 / 2}$ raste s porastom $T_{\text {ci }}$

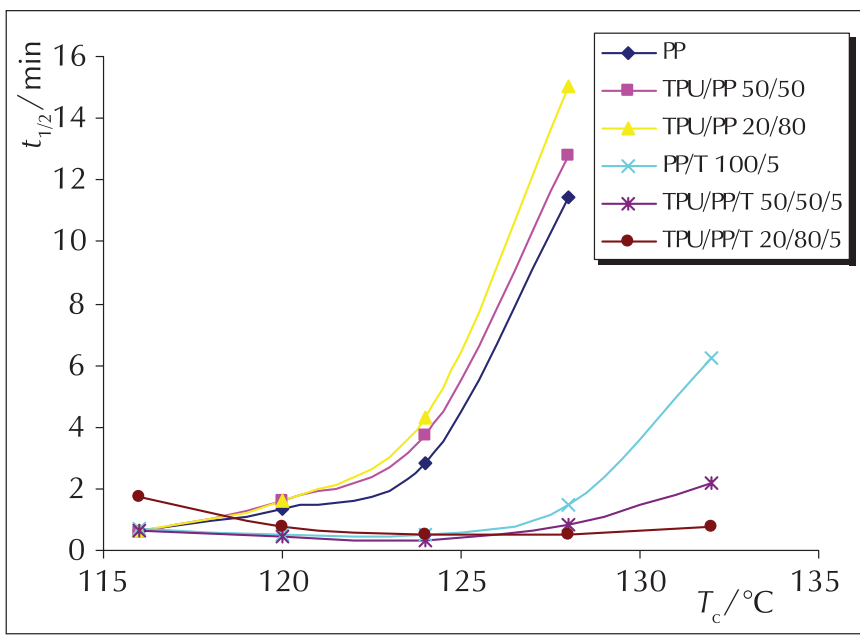

Slika 15 - Ovisnost polovičnog vremena kristalizacije $\left(t_{1 / 2}\right)$ o temperaturi kristalizacije $\left(T_{\mathrm{c}}\right)$ pri različitim udjelima PP-a

Fig. 15 - Plot of crystallization half-time of $\left(t_{1 / 2}\right)$ vs. crystallization temperature $\left(T_{\mathrm{c}}\right)$ for different PP fractions

\section{Zaključci}

Povećanjem udjela PP-a u mješavinama TPU/PP dolazi do porasta $t_{1 / 2}$. Vrijednosti $t_{1 / 2}$ za mješavine TPU/PP/talk znatno su niže od mješavina TPU/PP, tablica 2. Taj rezultat ukazuje na to da je kristalizacija mješavina TPU/PP/talk pri istoj $T_{\text {ci }}$ puno brža od kristalizacije mješavina TPU/PP. Prema tome, talk može djelovati kao sredstvo za nukleaciju i ubrzati kristalizaciju.

Kod kinetike izotermne kristalizacije Avramijev eksponent $n$ izračunat je za $X_{\mathrm{t}}$ - relativnu kristalnost $\mathrm{i}$ dobivene su vrijednosti u rasponu od 1,18 do 2,31 za čisti PP i PP/talk i unutar područja od 1,59 do 2,48 za mješavine TPU/PP i TPU/PP/talk. Ustanovljeno je da dobiveni rezultati prema definiciji Avramijevog eksponenta odgovaraju mehanizmu dvodimenzijskog rasta kristala PP.

Povećanjem udjela PP-a Avramijev eksponent raste, dok je dodatkom talka u svim mješavinama PP/TPU/talk uglavnom 2. Vrijednost Avramijeve konstante za PP i mješavine TPU/PP pada s povećanjem $T_{\text {ci }}$. Polovično vrijeme kristalizacije $t_{1 / 2}$ znatno je dulje za mješavine TPU/PP u odnosu na mješavine TPU/PP/talk, što ukazuje na to da je stupanj izotermne kristalizacije mješavina TPU/PP/talk na istoj $T_{\mathrm{ci}}$ brži od mješavina TPU/PP te da dodatak talka može povećati stupanj kristalizacije. Porastom temperature izotermne kristalizacije raste vrijeme potrebno za kristalizaciju. 


\section{Popis kratica i simbola List of abbreviations and symbols}

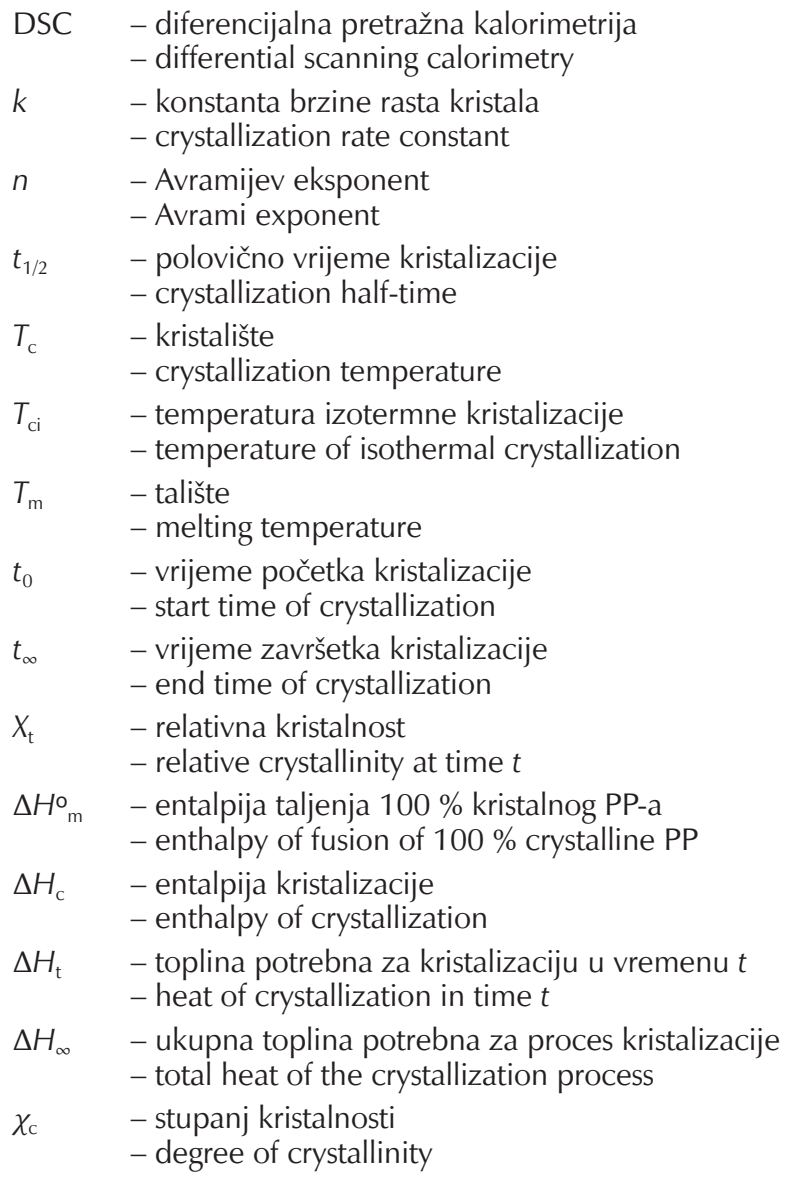

\section{Literatura \\ References}

1. A. Jeziorny, Parameters characterizing the kinetics of the non-isothermal crystallization of poly(ethylene terephtha- late) determined by d.s.c., Polymer 19 (1978) 1142-1144, doi: https://doi.org/10.1016/0032-3861(78)90060-5.

2. T. Ozawa, Kinetics of non-isothermal crystallization, Polymer 12 (1971) 150-158, doi: https://doi.org/10.1016/00323861(71)90041-3.

3. T. Liu, Z. Mo, S. Wang, H. Zhang, Nonisothermal melt and cold crystallization kinetics of poly(aryl ether ether ketone ketone), Polym. Eng. Sci. 37 (1997) 568-575, doi: https:// doi.org/10.1557/jmr.2016.68.

4. P. Supaphol, J. E. Spruilell, Crystalline memory effects in isothermal crystallization of syndiotactic polypropylene, J. Appl. Polym. Sci. 75 (2000) 337-346. doi: https://doi. org/10.1002/(SICI)1097-4628(20000118)75:3<337::AID -APP1>3.0.CO;2-4.

5. B. Wunderlich, Macromolecular Physics, Vol. 3, Crystal Melting, Academic Press, New York (1980) 63.

6. J. I. Velasco, J. A. De Saja, A. B. Martinez, Crystallization behavior of polypropylene filled with surface-modified talc, J. Appl. Polym. Sci. 61 (1996) 125-132, /doi: https://doi. org/10.1002/(SICI)1097-4628(19960705)61:1<125::AID -APP14>3.0.CO;2-6.

7. E. P. Collar, O. Laguna, S. Areso, J. M. Garcia-Martinez, Succinyl fluorescein grafted atactic polypropylene as an interface modifier in polypropylene/talc composites: a thermal study under dynamic conditions, Europ. Polym. J. 39 (2003) 157163, doi: https://doi.org/10.1016/S0014-3057(02)00193-3.

8. J. N. Hay, M. Sabr, Crystallization kinetics of high polymers. Polyethylene oxide - Part II, Polymer 10 (1969) 203-211, doi: https://doi.org/10.1016/0032-3861(69)90031-7.

9. J. N. Hay, P. A. Fitzgerald, M. Willes, Use of differential scanning calorimetry to study polymer crystallization kinetics, Polymer 17 (1976) 1015-1018, doi: https://doi. org/10.1016/0032-3861(76)90177-4.

10. B. Wunderlich, Macromolecular Physics, Vol. 2, Academic Press, New York, (1976) 132-147.

11. P. Supaphol, Application of the Avrami, Tobin, Malkin, and Urbanovici-Segal macrokinetic models to isothermal crystallization of syndiotactic polypropylene, Termochim. Acta 370 (2001) 37-48, doi: https://doi.org/10.1016/S00406031(00)00767-X. 


\section{SUMMARY}

\section{Kinetics of Isothermal Crystallization for TPU/PP Blends \\ Emi Govorčin Bajsić a* and Bojana Ormuž Pavićb}

The kinetics of isothermal crystallization and crystalline structure of thermoplastic polyurethane and polypropylene (TPU/PP) and thermoplastic polyurethane, polypropylene blends with addition of talc (TPU/PP/T) of different composition ratios (80/20, 50/50 and 20/80) were studied under isothermal conditions by differential scanning calorimetry (DSC). Crystallization studies were carried out in the temperature range of $116{ }^{\circ} \mathrm{C}$ to $132{ }^{\circ} \mathrm{C}$. It was found that crystallization was faster for TPU/PP/T blends. Isothermal crystallization kinetics were described by means of the Avrami equation. The effects of different isothermal temperatures were studied by comparing the values of kinetic parameters, such as the Avrami exponent, $n$, the kinetic constant of the crystallization rate, $k$, and the crystallization half-time, $t_{1 / 2}$. The Avrami exponent was evaluated to be in the range of 1.18-2.31. The results indicated the two-dimensional growth of crystalline units. The isothermal crystallization kinetics showed that the addition of talc increased the isothermal crystallization temperature and the crystallization rate constant, $k$, of TPU/PP blends. For the given crystallization temperatures, the crystallization half-time, $t_{1 / 2}$, for the TPU/PP/T blends was lower than the corresponding value for TPU/PP blends.

\section{Keywords}

Polypropylene, thermoplastic polyurethane, differential scanning calorimetry, isothermal crystallization, kinetics of crystallization

a University of Zagreb

Faculty of Chemical Engineering and Technology

Marulićev trg 19, 10000 Zagreb, Croatia

${ }^{\mathrm{b}}$ Ministry of Environmental and Nature Protection, Radnička cesta 80, 10000 Zagreb,

Croatia
Original scientific paper Received September 9, 2017 Accepted October 11, 2017 